World Bank Policy Research Paper

Number O-2834

March 2004

\title{
Aid, Policies, and Growth: Revisiting the Evidence*
}

\author{
By Craig Burnside ${ }^{\dagger}$ and David Dollar
}

Abstract: We revisit the relationship between aid and growth using a new data set focusing on the 1990s. The evidence supports the view that the impact of aid depends on the quality of state institutions and policies. We use an overall measure of institutions and policies popular in the empirical growth literature. The interaction of aid and institutional quality has a robust positive relationship with growth that is strongest in instrumental variable regressions. There is no support for the competing hypothesis that aid has the same positive effect everywhere. We also show that in the 1990s the allocation of aid to low-income countries favored ones with better institutional quality. This "selectivity" is sensible if aid in fact is more productive in sound institutional and policy environments. The cross-country evidence on aid effectiveness is supported by other types of information as well: case studies, project-level evidence, and opinion polls support the view that corrupt institutions and weak policies limit the impact of financial assistance for development.

\footnotetext{
* We would like to thank Aart Kraay for helpful comments on an earlier draft and Victoria Levin for excellent research assistance. Views expressed in this paper are those of the authors and do not necessarily reflect official views of the World Bank.

† Department of Economics, University of Virginia; burnside@virginia.edu

*DECVP, World Bank; ddollar@worldbank.org
} 


\section{Aid, Policies, and Growth: Revisiting the Evidence By Craig Burnside and David Dollar}

In Sub-Saharan Africa, 84\% of opinion makers agreed with the statement that, "Because of corruption, foreign assistance to developing countries is mostly wasted."

- Opinion survey commissioned by the World Bank and conducted by Princeton Survey Research Associates

In "Aid, Policies, and Growth" (Burnside and Dollar 2000b) we provided evidence that aid accelerates growth in developing countries with sound institutions and policies, but has less or no effect in countries in which institutions and policies are poor. We found these results quite intuitive: a corrupt, incompetent government is not going to use aid wisely and outside donors are not going to be able to force it to change it habits. This evidence is supportive of the growing trend among aid agencies toward greater "selectivity" - that is, channeling relatively more aid resources to poor countries with reasonably good institutions and policies. The United States's proposed Millenium Challenge Account is a recent example of this trend.

Since we initially presented our results in a working paper in 1996, critics have taken issue with them. However, our critics have not been able to agree among themselves about what the right model is: some find that aid never works anywhere (suggesting that it should be eliminated) while others find that it has a positive effect everywhere (suggesting that it should be given out indiscriminately). The main purpose of this paper is to take a fresh look at the issue based on a new data set focusing on the 1990s.

It is useful to start where there is agreement. Most development economists believe that underlying economic institutions and policies are the main determinants of long-term growth. Hall and Jones (1999), for example, argue that "differences in capital accumulation, productivity, and therefore output per worker are fundamentally related to differences in social infrastructure across countries. By social infrastructure we mean the institutions and government policies that determine the economic environment within which individuals accumulate skills, and firms accumulate capital and produce output." 
Similarly, Acemoglu, Johnson, and Robinson (2001) conclude their study of "The Colonial Origins of Development" by noting that "Many economists and social scientists believe that differences in institutions and state policies are at the root of large differences in income per capita across countries." There is some disagreement about the relative importance of different institutions and policies, but that is not germane to our argument. We have not attempted to identify exactly which institutions and policies are important for aid effectiveness: rather we are interested in the question of whether the whole package of growth-enhancing institutions and policies is also a determinant of the productivity of aid.

A second area of agreement concerns the effect of aid on institutions and policies. Researchers coming from the left, the right, and the center have all concluded that aid as traditionally practiced has not had systematic, beneficial effects on institutions and policies [Mosley, Harrigan, and Toye (1995); Rodrik (1996); Ranis (1995); Collier (1997); Dollar and Svensson (2000); Devarajan, Dollar, and Holmgren (2000)]. In particular, there is broad agreement that giving a large amount of financial aid to a country with poor economic institutions and policies is not likely to stimulate reform, and in fact may retard it. More generally, we concur with Acemoglu, Johnson, and Robinson (2001) that "there is little agreement ... about what determines institutions and government attitudes toward economic progress...." Their work, and the work of Engerman and Sokoloff (1997), indicate that institutions are often quite persistent, but there are historical examples of significant reforms.

Given that institutions and policies are important for growth and that aid has had little systematic effect on institutions and policies, we introduced the hypothesis that the impact of aid on growth is conditional on these same institutions and policies. To investigate this empirically we created a policy index based on several variables used in the empirical growth literature (and in a follow-up paper, Burnside and Dollar (2000a), we added a rule of law measure to the index), and found that aid had a positive effect on growth in developing countries with significantly better than average institutions and policies, whereas aid had no positive effect in countries with average policies. It is useful for the non-technical reader to provide a simple graphical representation of these findings, which we have updated in Burnside and Dollar (2003a). We regress growth, 
policy, and aid on the other variables (reflecting initial conditions) on the right-hand side of the growth regression, and extract the unexplained (residual) component of each variable. We then sort the data into 9 groups using the 33.3 and 66.7 percentiles of aid and policy. The average growth rate for each group appears to depend on the interaction between aid and policy (Figure 1). To us this graph shows that institutions/policies matter (something that is not in dispute). But the graph also shows that the effect of aid on growth also appears to depend on the level of policy. When policy is bad, the level of aid seems to have little impact on growth; if anything, a slightly negative impact. But for countries with good policies, giving sufficiently more aid seems to have a very positive impact on growth. The key statistical question is whether the impact of aid on growth is different for the poor-policy observations than for the good-policy observations.

Figure 1. Growth, Aid, and Policy

\section{Growth, aid and policy}

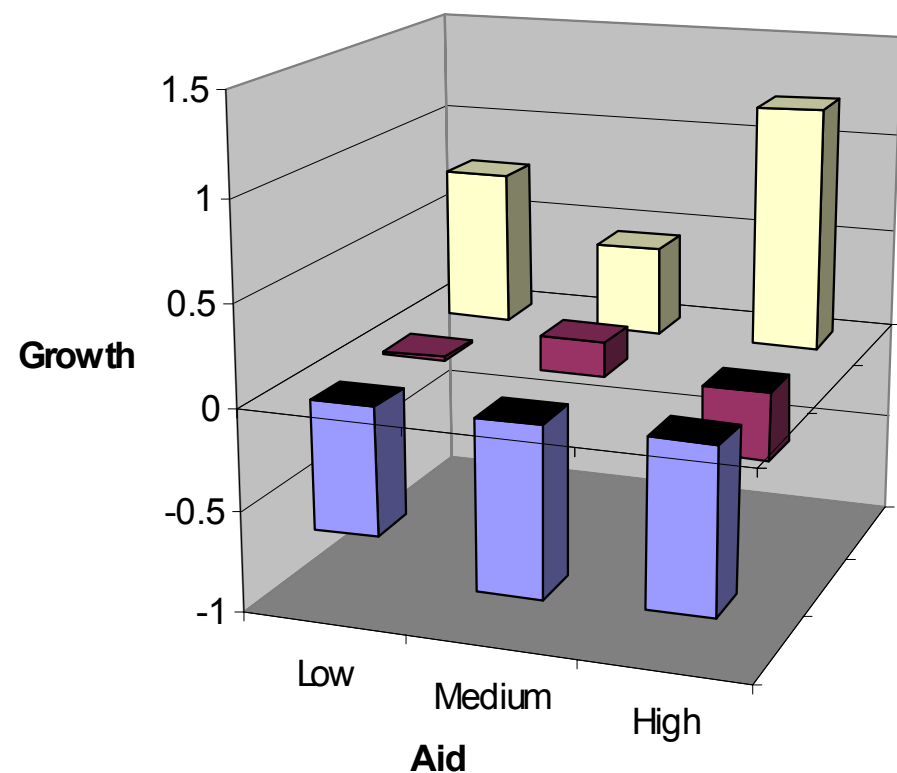

\section{Bad Policy $\square$ Medium Policy $\square$ Good Policy}


As noted, a number of papers have subsequently criticized our work. ${ }^{1}$ Common to many of these criticisms is a change in specification, either in terms of estimation technique, or in terms of which variables are included in the regression that explains growth. Subject to these changes, the interaction term between aid and a measure of institutions and policies sometimes loses significance. ${ }^{2}$ In one case, Easterly, Levine and Roodman (2003) expand our original data set as well as change the specification. Figure 1 is drawn with their data set, so simply expanding the data set in terms of the number of countries and time periods covered does not alter the relationship that we found. Elsewhere, in Burnside and Dollar (2003a, 2003b), we respond in detail to the specifics of these criticisms. However, we doubt that further work with that original data set (even expanded) is going to shed new light on this debate.

Our main contribution here is to build a new data set focusing only on the 1990s. We want to keep our eye on the policy question that motivated us: should aid allocations take account of differences in institutions and policies? There are three mutually exclusive, if not exhaustive, hypotheses concerning this interaction of aid and institutions/policies:

1. Aid has a positive effect on growth that is the same regardless of the quality of institutions and policies (that is, aid works the same in Mugabe's Zimbabwe as in reformist Uganda).

2. The effect of aid on growth is conditional on the same institutions and policies that affect growth directly, so that growth-enhancing institutions such as property rights and rule of law make aid more effective.

3. Aid has no positive effect in any institutional environment: it is always money down the rat hole.

The answer to our policy question depends on which of these hypotheses is correct.

\footnotetext{
${ }^{1}$ Among our critics are Hansen and Tarp (2000, 2001), McPherson (2000), Dalgaard and Hansen (2001), Dayton-Johnson and Hoddinott (2001, 2003), Guillaumont and Chauvet (2001), Lensink and White (2001), Lu and Ram (2001), Akhand and Gupta (2002) and Easterly, Levine and Roodman (2003). Collier and Dollar (2002), on the other hand, find a result similar to ours working with a different measure of institutions and policies.

${ }^{2}$ Actually, we, ourselves, showed several specifications for which the result did not hold, so we should be listed among our critics.
} 
The paper proceeds as follows: In Section 1 we examine the evidence on aid allocations. Using data for a large cross-section of developing countries, we show that in the 1980 s the amount of aid a country received was not correlated with institutional quality, as measured by the Freedom House democracy index or the ICRG rule of law index, once population and income level are taken into account. On the other hand, our data set suggests that in the 1990s the picture changed: countries with better institutions received significantly more aid. One standard deviation higher on the indices of rule of law and of democracy corresponded to $28 \%$ more overall aid and $50 \%$ more finance from the World Bank IDA facility (which is part of foreign aid). Our paper is not concerned with why this apparent shift in donor behavior has come about. It may be a spillover benefit from the end of the Cold War; it may reflect deliberate decisions by donors to stop funding corrupt governments; and/or it may be a coincidence. Our concern, rather, is whether this shift - whatever its source - led to an allocation of foreign aid that has more impact on growth and poverty reduction in the developing world than aid has had in the past.

In Section 2 we turn to our policy question. Using a new cross-section data set for the $1990 \mathrm{~s}$, and a measure of overall institutional quality that is currently popular in empirical growth studies, we find our original result to be quite robust if the focus is on choosing between hypotheses 1 and 2 . There is simply no cross-country evidence that aid promotes growth in every environment. On the other hand, we find considerable support for hypothesis 2 in this new data set, particularly when we estimate our model using instrumental variables techniques. In fact, we find the institutions-aid interaction to be more robust than institutions by themselves.

Given that the number of countries in the world is finite, we suspect that one can always make the coefficient of interest lose significance. We find specifications, for example, in which there is no significant link between institutions and growth. So, in choosing between hypotheses 2 and 3, we doubt that cross-country empirical work alone can settle the debate. Inevitably, there will be specifications in which the aid-institutions interaction is not significant.

Since we doubt that cross-country regressions will settle the policy debate, in Section 3 we briefly survey other information that is relevant. The argument that aid has 
a positive effect, but that its effect is conditional on having good institutions, has additional support from theory, case studies, and project level evidence. Also convincing is the recent poll of "opinion makers" in developing countries quoted above; it found overwhelming support for the view that corruption often limits the effectiveness of aid [PSRA (2003)]. We would like to think that all this evidence, together, has encouraged a shift in the allocation of aid, away from an indiscriminate distribution toward one that favors developing countries with reasonably good institutions and policies.

\section{Shifting Aid Allocation from the 1980s to the 1990s}

In studying the relationship between institutions and growth, researchers have used a number of different measures of institutional quality. Several recent studies [Easterly and Levine (2003); Kaufmann, Kraay, and Zoido-Lobaton (1999)] use an overall index of institutional quality that is compiled by standardizing and averaging all of the different institutional variables available in the second half of the 1990s (hereafter referred to as KKZ). This overall measure is ideal for our growth analysis in the next section, because we need a summary measure of growth-enhancing institutions and policies to interact with aid and this particular measure is available for more than 120 countries in the 1990s. However, in this section we want to look at how the allocation of aid has changed between the 1980s and 1990s, and for this we need institutional quality measures that are available over a longer span of time.

Some of the other institutional quality measures that have been used in the empirical growth literature are: the rule of law component from the KKZ aggregation [Dollar and Kraay (2003); Rodrik, Subramanian, and Trebbi (2002)]; the International Country Risk Guide (ICRG) expropriation risk index [Acemoglu, Johnson, and Robinson (2001)]; composite ICRG and Business Environmental Risk Intelligence (BERI) indexes [Knack and Keefer (1995)]; an index combining five ICRG indicators with the SachsWarner openness index [Hall and Jones (1999)]; the bureaucratic efficiency, political stability and institutional efficiency indexes composed of nine Business International (BI) indicators [Mauro (1999)]; and the composite ICRG index and the Freedom House 
democracy index [Rodrik (1999)]. The latter two have the advantage that they are available for many developing countries going back to the 1980s.

To see how the allocation of aid has changed over time, we regress the log of net aid receipts of each developing country (annual average in the 1980s) on log per capita income in 1980 (and its square), log population in 1980 (and its square), and the averages, in the 1980s, of two institutional quality measures: the ICRG rule of law index (which ranges from 1 to 6 , where a higher number indicates better rule of law) and the Freedom House democracy index (ranging from 1 to 3, where a higher number is more authoritarian). We should emphasize that this is not a model of donor behavior. There is a literature that explains donor allocations in terms of economic and political variables [Alesina and Dollar (2000); Boschini and Olofsgard (2002)]. We have a more modest ambition here, which is simply to look at how much assistance is going to countries with differing institutional quality, after controlling for per capita income and population.

In the ODA equation for the 1980s there is a modest relationship between aid and democracy, but it is not significantly different from zero (Table 1). ${ }^{3}$ The relationship between aid and rule of law is negative, but again not significant. It is also interesting to look at the allocation of the World Bank's IDA facility, funds that are contributed by OECD donors and counted as part of overall aid. In the 1990s the contributors stipulated that these funds should be allocated in favor of poor countries with sound institutions and policies. In the 1980s it can be seen that the allocation of IDA was similar to the allocation of overall ODA: no significant relationship with institutional quality. IDA funds are only given to low-income countries, whereas much of total ODA goes to middle-income countries. Table 1 also shows the allocation of ODA, with the coverage constrained to the 42 low-income countries that received IDA. The basic point here is that in the 1980s there was not much relationship between institutional quality, on the one hand, and how much ODA or IDA a country received, on the other. One standard deviation more democratic plus one standard deviation better rule of law corresponded to $3 \%$ more aid and $11 \%$ more IDA in the 1980 s.

Similar regressions for the 1990s reveal a changed picture: both ODA and IDA are positively correlated with institutional quality. For ODA as a whole, the relationship

\footnotetext{
${ }^{3}$ The variables and the sources of data are described in detail in the appendix at the end of the paper.
} 
is not that strong. The individual t-statistics on the Freedom House and ICRG measures are not that large. However, democracy and rule of law are positively correlated across countries so that it is important to look at the joint test as well. The p-value for the joint test that the two coefficients are zero is 0.17 for total ODA. For IDA there is a stronger relationship; Freedom House and ICRG are both significant, and the p-value for the joint test is below 0.01 . Finally, the joint test is significant at the 2 percent level for total ODA, if the coverage is constrained to low-income countries (Column 6). The coefficients indicate that one standard deviation better on both institutional measures corresponds to $28 \%$ more ODA and $50 \%$ more IDA. Again, we are not taking a stand on why this shift has come about. But as a factual matter, we can say, in general, that where there are countries of equal poverty and population but differing institutional quality, the country with better institutions received more aid in the 1990s - and that that was not the case in the 1980s.

Figures 2 and 3 show these relationships for IDA. These are partial scatters: on the horizontal axis is the part of rule of law uncorrelated with the other variables in the regression, so it can be thought of as an index of unexpectedly good and bad rule of law. The vertical axis indicates which countries are getting unexpectedly large amounts of IDA. It is very clear that in the 1980 s there was no relationship at all between how much IDA countries were receiving and which countries had relatively good rule of law. In the 1990s, on the other hand, there is now a clear relationship. In the upper-right quadrant one finds a number of well-known reformers (China, Uganda, Ghana) receiving amounts of IDA that were large given their per capita incomes and population; in the lower-left, on the other hand, countries such as Haiti, Nigeria, Angola, and DR Congo have unexpectedly poor institutions and lower amounts of IDA. 
Figure 2. IDA and Rule of Law, 1980s

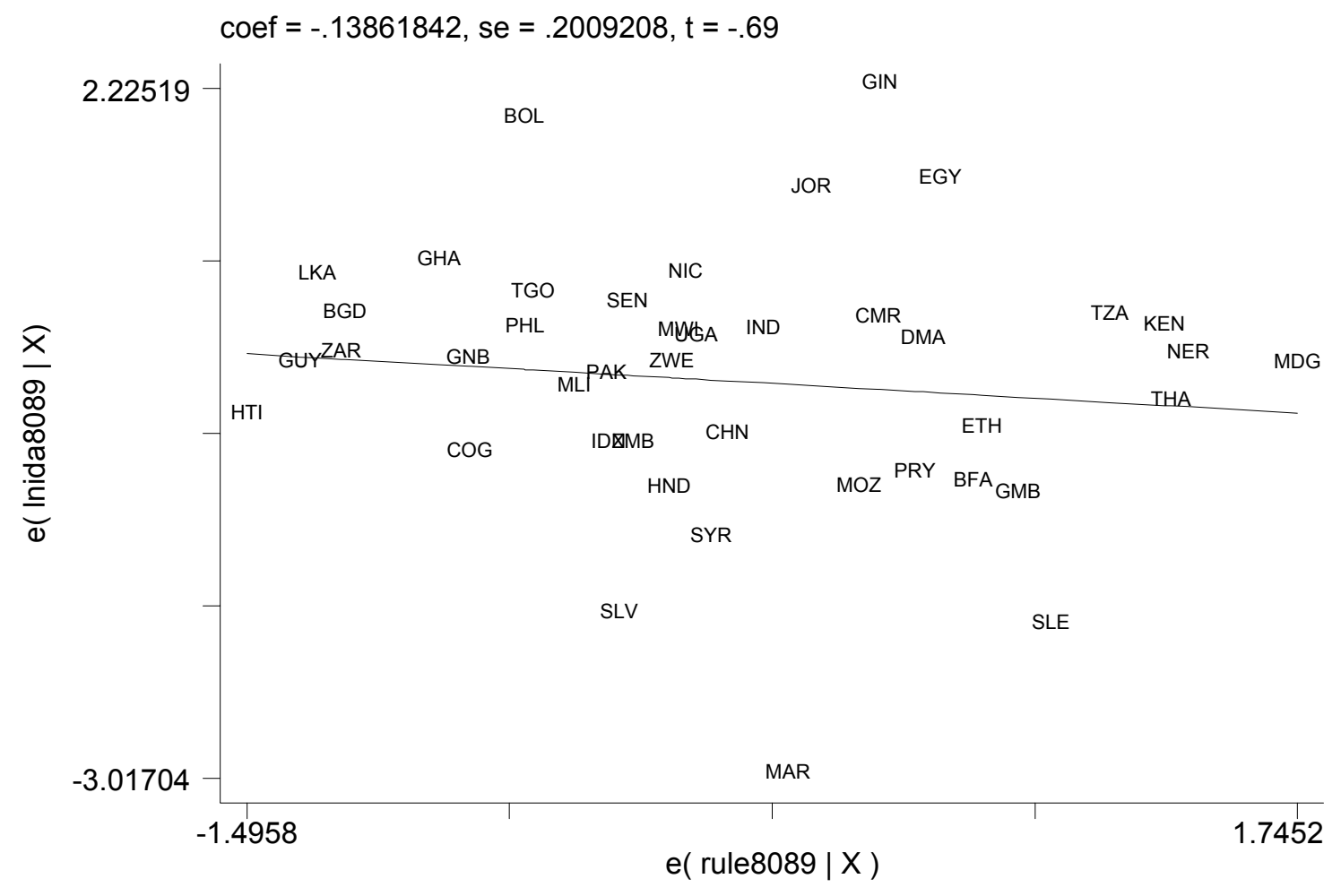

We think that this is useful background for the debate about the robustness of the aid variable in cross-country growth regressions. Referring back to the three hypotheses that we noted in the introduction: if you think that the evidence supports hypothesis 1 , then this shift that we have documented is a bad thing that should be reversed by giving more aid to countries with poor institutions; if you think that the evidence for hypothesis 2 is pretty robust, then this shift - whatever its initial source - is a positive trend that should be encouraged; and if you think that the evidence supports hypothesis 3 then it would be logical to oppose any aid programs aimed at promoting growth in the developing world. 
Figure 3. IDA and Rule of Law, 1990s

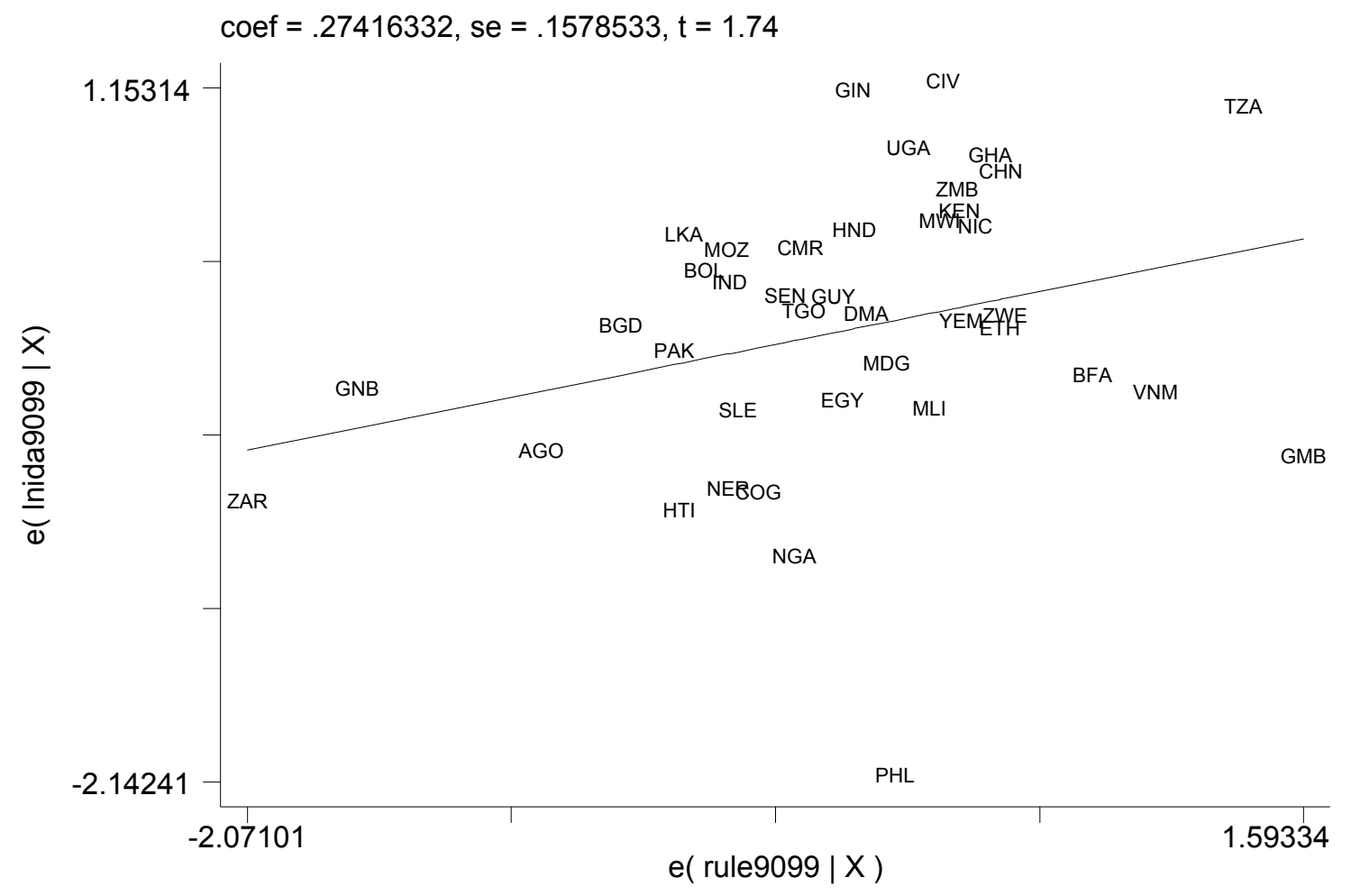

\section{Aid and Growth}

The basic hypothesis that we want to explore is that the effect of aid depends on the same institutions and policies that affect growth directly. For this analysis we need a good summary measure of institutions and policies. In our original paper we constructed our own index. But in light of the recent literature on institutions and growth, it now seems to us to make more sense to use one of the overall indices used in the literature. ${ }^{4}$ The one that provides the best country coverage in the 1990s is the overall institutional quality measure from KKZ, which enables us to include 124 countries in our regressions. To link back to Section 1, the KKZ measure standardizes and averages other institutional

\footnotetext{
${ }^{4}$ In retrospect creating our own policy index resulted in limiting the country coverage to countries for which we had all the component data. The limited number of countries in turn was one reason why we organized the data into a panel with four-year periods. One thing that we have learned from the dialogue with our critics is that most of the variation in the variable of interest, aid interacted with institutions/policies, is cross sectional. Therefore, organizing the data into a panel is not particularly useful. Here, we focus on a single cross section for the decade of the 1990s - the era after the end of the Cold War.
} 
quality indices, such as the ICRG rule of law measure and the Freedom House democracy measure. When we regress the overall measure of institutional quality in the 1990s from KKZ on the ICRG rule of law index and the Freedom House index, the $R^{2}$ is . 82 and the t-statistic on each measure is over 10 - indicating that the KKZ measure basically combines the information from those sources. We take the $\mathrm{KKZ}$ measure as an index of the extent to which a country's overall institutions and policies create a good environment for entrepreneurship and growth.

Before introducing the interaction of institutional quality and aid, let us examine whether there is any evidence of a direct relationship between aid and growth, not mediated by institutions. We start with OLS regressions of average annual per capita GDP growth in the 1990s on initial per capita GDP in 1990, the institutional quality measure, and receipts of aid relative to GDP. As a measure of aid we take net Official Development Assistance flows as reported by the OECD. We have the requisite data for 124 countries. We will treat all of the right-hand-side variables as endogenous, but it is useful to start with OLS regressions to understand the patterns in the data.

Growth in the 1990s is negatively correlated with initial income (suggesting conditional convergence) and positively associated with institutional quality; after controlling for these there is a negative coefficient on aid that is significant at the 10 percent level (Table 2, Column (1)). This is an important point that we want to emphasize. After controlling for initial income and the quality of institutions, there is a pretty strong negative correlation between aid and growth, which is depicted in the partial scatter of Figure 4. Anyone who wants to argue that aid works well in all institutional environments is swimming upstream against this evidence. Column 2 introduces a full set of regional dummies corresponding to the World Bank's classification: East Asia (EAP), South Asia (SAR), Middle East and North Africa (MNA), Sub-Saharan Africa (AFR), Latin America and the Caribbean (LAC), and Former Soviet Union (FSU) with rich countries as the default. ${ }^{5}$ In general, as we proceed through the analysis, we do not find these regional dummies to consistently be important, with the exception of EAP,

\footnotetext{
${ }^{5}$ We use the Former Soviet Union as a regional designation rather than the World Bank Region that includes the FSU called Europe and Central Asia (ECA). When we included an ECA dummy, rather than an FSU dummy, it was significant, but with both dummies included only the FSU dummy was significant.
} 
SAR, and FSU. With these three regional dummy variables included, aid has a negative coefficient, but it is no longer significant.

Figure 4. Aid and Growth in the 1990s (no regional dummies)

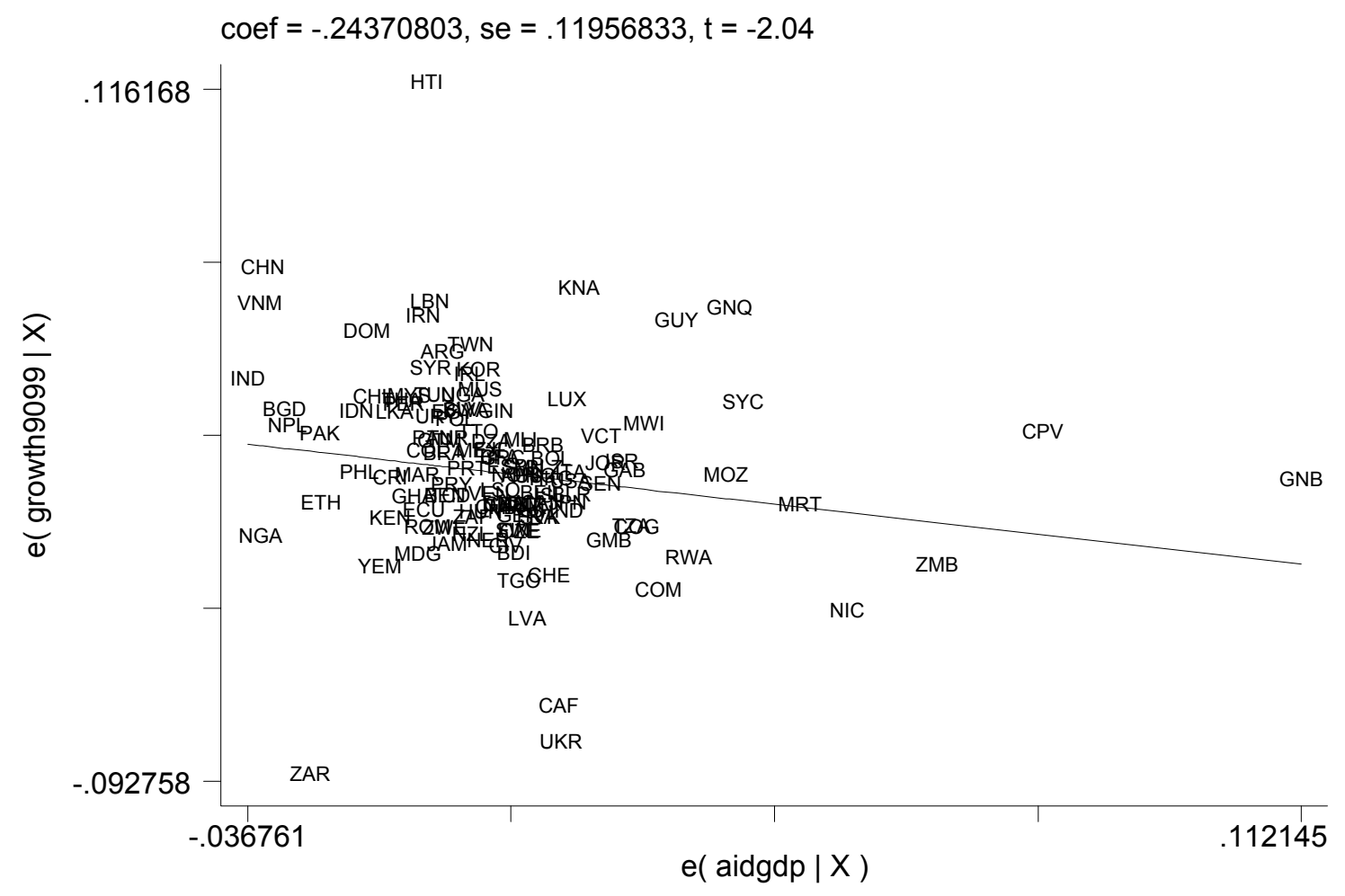

The second panel in Table 2 shows the same specifications, but now initial income, institutions, and aid are all treated as endogenous. There are good reasons to treat each of the right-hand-side variables as endogenous. In the case of aid, it is very possible that the negative correlation between aid and growth reflects the endogenous response of aid donors to countries hit by unexpected shocks or crises. Without instrumental variables, growth regressions involving aid are suspect. In the case of initial per capita GDP, measurement error would introduce a negative correlation between initial income and subsequent growth. In the case of the institutions variable, we are not too worried about reverse causation from fast growth to good institutions in a ten-year period. However, all of the institutional quality variables are essentially subjective, and there is a danger of a "halo effect" in which fast-growing countries are rated to have good 
institutions. Since the measure we use comes from 1996, which is in the middle of the decade of growth that we are studying, we take the issue of the halo effect seriously. By using instrumental variables we hope to deal with this issue.

We use an instrument set that has been developed in cross-sectional growth empirics: (i) the share of the population that speaks English, (ii) the share that speaks a continental European language, (iii) distance from the equator, (iv) the logarithm of population, and (v) the logarithm of population interacted with each of the other variables. Other work has shown that the language and distance variables are correlated with per capita GDP in 1990 and with institutional quality. Recall, from Table 1, that population is highly correlated with aid receipts relative to GDP. Since we ultimately want to instrument for institutions interacted with aid, it makes sense to interact population with the other exogenous variables. It is difficult to instrument for three (and ultimately four) variables at once, and below we examine the question of how valid and relevant the instruments are.

In the Table 2 IV regressions, aid continues to have a negative coefficient in the specification without regional dummies, but now the coefficient is not significantly different from zero. We start with this table to make two points. First, in three out of six specifications aid has a negative coefficient. If one is looking for evidence of hypothesis 1, that aid has the same positive effect on growth everywhere, it is difficult to find any encouragement in the growth evidence from the 1990s. A second important point is that even for a variable that is considered very robust in the growth literature, such as institutional quality, it is not hard to find plausible specifications in which the variable is not statistically significant, as is the case in all three IV regressions.

The results may reflect problems with the instruments. Table 3 shows the firststage regressions. For initial income and institutions, the $R^{2}$ s are 0.60 , while for aid (0.37) and aid interacted with institutions (0.26) they are fairly high as well. However, with several endogenous variables the first-stage regressions by themselves do not indicate whether the instruments are good. Some additional insight comes from Table 4, which shows correlation among the right-hand-side variables and the predicted values from the first-stage regressions. For each variable the predicted value is highly correlated with the actual value. But a potential problem is that predicted 1990 per capita GDP and 
predicted institutions have a correlation of 0.98 . On the other hand, the correlations among predicted aid, predicted institutions, and the predicted interaction term are not worrisome. We will address this issue more formally below.

Returning to the aid-growth relationship, Hansen and Tarp argue that aid has a positive effect in all institutional/policy environments, but that it is subject to diminishing returns. In Table 5 we test for this by including the square of aid relative to GDP. In OLS there is a negative coefficient on aid and a positive one on aid squared (the opposite of diminishing returns), but these results are not robust. So, even allowing for diminishing returns, there is no evidence of an unconditional positive link from aid to growth.

Now we introduce the interaction of institutions and aid, and instrument for the four right-hand-side variables with the same instrument set (Table 6). With no regional dummies (Column 3), the aid-institutions interaction is strongly positive and significant at the 10 percent level, while none of the other variables is significantly different from zero. Adding the three regional dummies (Column 4) does not alter the coefficients very much, but now the aid-institutions interaction just misses being significant at the 10 percent level. Other than regional growth patterns, the thing we have most confidence in from the 1990s is that the combination of good institutions and foreign aid supports rapid growth in the developing world.

We were curious that in the OLS specifications (Columns 1 and 2) the coefficient on the aid-institutions interaction was positive, yet insignificant, in contrast to the IV regression. Looking at the data, we found two countries that were anomalous in the sense that they were reported to have very poor institutions, but extremely rapid growth in the 1990s: Haiti and Equitorial Guinea. Table 7 shows the four specifications without these two countries. Note that the IV regressions are nearly identical with those in table 6, but with increased statistical significance for the aid-institutions interaction (5 percent level). The fact that the IV regressions are quite similar with and without the outliers suggests that instrumenting has effectively dealt with measurement error. But the OLS regressions turn out to be heavily influenced by those two observations. Without them, the OLS regressions show the same strong relationship between growth, on the one hand, and aid interacted with institutions, on the other, that we find in the IV regressions. 
What do we make of the size of the estimated coefficients? The KKZ index has a mean of zero and a standard deviation of 1.0. But that is across all countries, including developed ones. Large-scale aid mostly goes to low-income countries, where values of the KKZ index are negative or slightly greater than zero. The coefficients estimated from the full sample (Table 6) indicate that the marginal impact of aid on growth in India is in the range of .16 (Column 3) to .34 (Column 4), equivalent to a 16-34 percent rate of return on investment. In neighboring Pakistan, with institutions measured to be far weaker, the marginal impact of aid is estimated to be negative. The quantitative estimate of what aid can accomplish in a good institutional environment is similar to what we found in our original paper.

We assess our choice of instruments in two ways. First, our IV regressions are based on the identifying assumption that the instruments are not correlated with the error term in the regression. Since we have more instruments than regressors, for each IV specification in tables 2-7 we report the p-value for a test of the over-identifying restrictions. In all specifications we cannot reject the null hypothesis that the instruments are orthogonal to the error term in the regression. In Tables 6 and 7, the p-values for this test range from .84 to .97 . We find this result very plausible: it essentially says that the historical and geographic variables that we use as instruments do affect growth in the 1990s, but they do so through their effect on 1990 per capita income, the quality of institutions, the level of aid, and the interaction of the latter variables.

Second, when attempting to instrument simultaneously for four right-hand side variables, it is important to determine whether the instruments collectively capture independent variation in the right-hand-side variables. We refer to this as instrument relevance. One approach to assessing the quality of the instruments is to look at the $R^{2} \mathrm{~s}$ from the first-stage regressions to see if the instruments are correlated with the right-hand side variables in the growth regression.. With four endogenous variables, however, this approach tells us very little. For example, it is possible that the first-stage regressions for two variables - say, institutions and 1990 per capita GDP — both look very good, in the sense that the $R^{2}$ s from these regressions are high. Nonetheless, it is also possible that the fitted values from these regressions are highly correlated with each other, so that it is difficult to identify their effects in the second stage regression. This situation would arise 
if just one instrument, say the share of English speakers, was providing most of the explanatory power in both first stage regressions.

We follow Shea (1997) in testing for the relevance of our instruments. The procedure is as follows. Take one of the right-hand side variables in the growth regression, say aid, $a$. Regress $a$ on the other right-hand-side variables of the growth regression. The residual from this regression, $\bar{a}$, is the new information that the aid variable brings to the OLS growth regression. Then run the first stage regressions, and construct the fitted value of aid, denoted $\hat{a}$. Regress $\hat{a}$ on the other fitted values from the first stage regressions for initial income, institutions, and aid interacted with institutions. The residual from this regression, $\widetilde{a}$, is the new information that aid brings to the IV regression. Finally, regress $\bar{a}$ on $\widetilde{a}$. The coefficient in this regression is 1.0 , by construction, but the p-value and $R^{2}$ indicate whether the information that the aid variable brings to the IV regression is in fact highly correlated with the information that aid brings to the OLS regression. I.e. they indicate whether the instruments have sufficient relevance for the right-hand side variables in the growth regression.

Table 8 shows the results for our test of instrument relevance for the four endogenous variables from specification 3 in table 6 . The tests suggest that our instruments are relevant in the sense that $\mathrm{p}$-values are all .001 or below and the $R^{2} \mathrm{~s}$ are all above .10 , except for institutions, for which it is 0.09 . We have already highlighted the potential problem of collinearity between predicted institutions and predicted 1990 per capita GDP. Our own reading of the literature is that the evidence for convergence over a period as short as a decade is mixed at best. So, in Table 9 we drop 1990 per capita GDP and simply run a horse race among institutions, aid, and aid interacted with institutions. In the IV regressions it is only aid interacted with institutions that is statistically significant.

A final robustness check is to treat initial per capita GDP and the institutions measure as exogenous and only instrument for aid and aid interacted with institutions (Table 10). Now, initial income and institutions have the intuitive signs, but are not statistically significant when we instrument for aid and aid interacted with institutions. Aid-institutions interaction is again positive with a p-value just above 0.05 in the specification without regional dummies. 
Thus, with a new data set covering a different period (the 1990s) and using a different index of institutions and policies, we find the same basic pattern that we identified in Burnside and Dollar (2000a,b): the combination of good institutions/policies and external aid appears to lead to more rapid growth.

\section{Conclusions}

In conclusion, our original finding that aid spurs growth conditional on the quality of institutions and policies is quite robust. We find the relationship in a new data set focusing on the 1990s and using an overall measure of institutional quality. Our strongest conclusion from the cross-country work is that there is far more evidence that aid spurs growth conditional on institutions, than for the competing hypothesis that aid has the same positive effect in all institutional environments. On the other hand, because all cross-country statistical results are fragile, we cannot completely reject the hypothesis that aid never works anywhere. Like most economists we believe that institutions and policies matter for growth, but it is possible to find specifications in which the institutional quality variable is not significant, so a limitation of the cross-country approach is that it cannot definitively settle some debates.

Fortunately, policy makers do not form judgments based simply on cross-country regressions. There are other types of information that are useful for those trying to establish effective aid policies. First, one should not underestimate the importance of theory. Given that institutions and policies affect growth, it is difficult to write down a coherent growth model — unless one assumes international capital markets are perfect-in which the impact of aid would not be conditional on the same institutions and policies. ${ }^{6}$ For aid to have no impact in a low-income country, regardless of the quality of institutions, would require a degree of perfection in international capital markets that we find implausible. So, based on theory, it is quite plausible that aid would promote growth in poor countries that manage to put good institutions into place.

A second type of information that is relevant comes from case studies. There is fairly broad agreement that the Marshall Plan accelerated European growth after World War II: this is the ideal example of the model we have in mind, with a significant volume

\footnotetext{
${ }^{6}$ See Burnside and Dollar (2000c).
} 
of finance pumped into an environment of solid institutions and social infrastructure. We would argue that this one case disproves hypothesis \#3, that aid is always money down the rat hole. There are quite a few case studies of aid to developing countries. Many of these support the view that money channeled to a highly corrupt government with distorted economic policies provides no lasting benefit. On the other hand, studies of successful aid typically emphasize that the recipient government had a good set of policies to enhance growth and directed assistance to useful investments in roads, schools, and the like.

A third type of evidence that is relevant comes from data on individual projects financed by aid. In a variety of sectors, projects are more likely to be successful in countries with growth-enhancing institutions and policies [Isham and Kaufmann (1999)]. When South Korea was a low-income country with a large amount of aid in the 1960s, most projects, of many different types, were successful. In Kenya and Zimbabwe in recent decades, on the other hand, many projects, of all types, have failed, in the sense that they have not provided the services or benefits anticipated from the investment. If aid were not fungible, this project level evidence would settle the debate. However, it is possible that all of the good projects in Korea would have been financed by private capital in the absence of aid, so that project-level evidence alone cannot settle the debate about aid effectiveness. Once we combine the evidence from case studies and projects with the cross-country correlations, however, we feel more confident that aid effectiveness depends on institutions and policies.

We were also interested to see the results of a global poll commissioned by the World Bank from a private survey company [PSRA (2003)]. The poll focused on "opinion makers" in a wide range of developing and developed countries (that is, government officials, academics, the media, trade union leaders, NGOs, etc.). In SubSaharan Africa, 84\% of opinion makers agreed with the statement that, "Because of corruption, foreign assistance to developing countries is mostly wasted." In other regions of the developing world, similarly large majorities agreed with the statement. Opinion makers in rich countries were the least skeptical (only 58\% agreed with the statement). So, while first-world academics may find some specifications in which aid works in all 
institutional environments, that argument is going to be a tough sell in the developing world.

A final important point in this debate concerns incentive effects. We and others have found that in the past aid has not systematically led to improvements in institutions and policies. But the phrase "in the past" is quite important. In the past aid has been allocated indiscriminately with regard to the institutions that are critical for growth. If the allocation rule changes, then the past evidence tells us little about what may happen in the future. We would not expect aid — even well managed — to to be a main determinant of reform. But if aid is systematically allocated to low-income countries with relatively good institutions, then we would expect that this would increase the probability that reforms are successful and politically sustainable. Thus, aid could be a useful support to reform even if it is not its main determinant. Our line of reasoning is speculative, but it is not unreasonable to think that allocating aid to relatively good governments would have a positive incentive effect.

Based on all the evidence, we think that it is good news that aid is now more systematically allocated to countries with sound institutions and policies. If anything, we would encourage aid-givers to strengthen this trend even more. 


\section{References}

Acemoglu, Daron, Simon Johnson and James A. Robinson (2001). "The Colonial Origins of Comparative Development: An Empirical Investigation." American Economic Review 91:5, pp. 1369-1401.

Akhand, Hafiz A. and Kanhaya L. Gupta (2002). Foreign Aid in the Twenty-First Century. Boston: Kluwer Academic Publishers.

Alesina, Alberto and David Dollar (2000). "Who Gives Foreign Aid to Whom and Why?" Journal of Economic Growth 5:1 (March), pp. 33-63.

Boschini, Anne and Anders Olofsgård (2002). "Foreign Aid: An Instrument for Fighting Poverty or Communism?" Working Paper.

Burnside, Craig and David Dollar (2000a). "Aid, Growth, the Incentive Regime, and Poverty Reduction," in Christopher L. Gilbert and David Vines, eds. The World Bank: Structure and Policies. Cambridge: Cambridge University Press.

Burnside, Craig and David Dollar (2000b). "Aid, Policies, and Growth." American Economic Review 90:4 (September), pp. 847-68.

Burnside, Craig and David Dollar (2000c). "Aid, Policies, and Growth: Technical Appendix on the Neoclassical Model." Unpublished manuscript, World Bank, November.

Burnside, Craig and David Dollar (2003a). "A Reply to New Data, New Doubts: A Comment on Burnside and Dollar's 'Aid, Policies, and Growth'.” Forthcoming, American Economic Review.

Burnside, Craig and David Dollar (2003b). "On the Effects of Aid on Growth: A Response to Criticisms and Some Thoughts on Methodology." Unpublished manuscript, University of Virginia, October.

Collier, Paul, and David Dollar (2002). "Aid Allocation and Poverty Reduction," European Economic Review.

Dalgaard, Carl-Johan and Henrik Hansen (2001). "On Aid, Growth and Good Policies." Journal of Development Studies 37:6 (August), pp. 17-41.

Dayton-Johnson, Jeff and John Hoddinott (2001). "Optimal Allocation of Development Aid Across Countries.” Unpublished manuscript, Dalhousie University, June.

Dayton-Johnson, Jeff and John Hoddinott (2003). "Aid, Policies, and Growth, Redux." Unpublished manuscript, Dalhousie University, April. 
Devarajan, Shantayanan, David Dollar and Torgny Holmgren, eds. (2000). Aid and Reform in Africa : Lessons from Ten Case Studies. Washington, DC : World Bank.Dollar, David and Aart Kraay (2003). "Institutions, Trade and Growth." Journal of Monetary Economics 50:1, pp. 133-162.

Dollar, David and Jakob Svensson (2000). "What Explains the Success or Failure of Structural Adjustment Programmes?" The Economic Journal 110:466 (October), pp. 894-917.

Easterly, William and Ross Levine (2003). "Tropics, Germs, and Crops: How Endowments Influence Economic Development.” Journal of Monetary Economics 50:1, pp. 3-39.

Easterly, William, Ross Levine and David Roodman (2003). "New Data, New Doubts: A Comment on Burnside and Dollar's 'Aid, Policies, and Growth'.” Forthcoming, American Economic Review.

Engerman, Stanley and Kenneth Sokoloff (1997). "Factor Endowments, Institutions, and Differential Paths of Growth Among New World Economics: A View from Economic Historians of the United States," in Stephen Haber, ed. "How Latin America Fell Behind: Essays on the Economic Histories of Brazil and Mexico 1800-1914." Stanford, CA: Stanford University Press.

Guillaumont, Patrick and Lisa Chauvet (2001). "Aid and Performance: A Reassessment." Journal of Development Studies 37:6 (August), pp. 66-92.

Hall, Robert E. and Charles I. Jones (1999). "Why Do Some Countries Produce So Much More Output per Worker than Others?" Quarterly Journal of Economics 114:1 (February), pp. 83-116.

Hansen, Henrik and Finn Tarp (2000). "Aid Effectiveness Disputed." Journal of International Development 12:3 (April), pp. 375-98.

Hansen, Henrik and Finn Tarp (2001). "Aid and Growth Regressions." Journal of Development Economics 64:2 (April), pp 547-70.

Isham, Jonathan and Daniel Kaufmann (1999). "The Forgotten Rationale for Policy Reform: The Productivity of Investment Projects." Quarterly Journal of Economics 114:1 (February), pp. 149-184.

Kaufmann, Daniel, Aart Kraay and Pablo Zoido-Lobatón (1999). "Aggregating Governance Indicators.” World Bank Policy Research Working Paper No. 2195.

Knack, Steven and Philip Keefer (1995). "Institutions and Economic Performance: Cross-Country Tests Using Alternative Measures." Economics and Politics 7:3, pp. 207-27. 
Lensink, Robert and Howard White (2001). "Are There Negative Returns to Aid?" Journal of Development Studies 37:6 (August), pp. 42-65.

Lu, Shuang and Rati Ram (2001). "Foreign Aid, Government Policies, and Economic Growth: Further Evidence from Cross-Country Panel Data for 1970-93."

Economia Internazionale 54:1 (February), pp. 14-29.

McPherson, Malcolm (2000). “Aid, Policies, and Growth: A Comment.” Unpublished manuscript, Harvard University.

Mosley, Paul, Jane Harrigan, and John Toye (1995). Aid and Power : the World Bank and Policy-Based Lending. New York : Routledge.

Princeton Survey Research Associates (PSRA) (2003). The Global Poll: Multinational Survey of Opinion Leaders 2002. Full Report, prepared for the World Bank.

Rodrik, Dani (1999). "Where Did All the Growth Go? External Shocks, Social Conflict, and Growth Collapses." Journal of Economic Growth 4:4, pp. 385-412.

Rodrik, Dani, Arvind Subramanian and Francesco Trebbi (2002). "Institutions Rule: The Primacy of Institutions over Geography and Integration in Economic Development.” NBER Working Paper No. 9305.

Shea, John (1997). "Instrument Relevance in Multivariate Linear Models: A Simple Measure." Review of Economics and Statistics 79:2, pp. 348-352. 
Table 1. Allocation of ODA and IDA in the 1980s and 1990s

\begin{tabular}{|c|c|c|c|c|c|c|}
\hline & \multicolumn{3}{|c|}{$1980 \mathrm{~s}$} & \multicolumn{3}{|c|}{$1990 \mathrm{~s}$} \\
\hline & (1) & (2) & (3) & (4) & (5) & (6) \\
\hline & $\begin{array}{c}\text { Log } \\
\text { average } \\
\text { annual net } \\
\text { ODA, } 1980- \\
1989\end{array}$ & $\begin{array}{c}\text { Log } \\
\text { average } \\
\text { annual } \\
\text { net IDA, } \\
\text { 1980-1989 }\end{array}$ & $\begin{array}{c}\text { Log } \\
\text { average } \\
\text { annual } \\
\text { net ODA } \\
\text { (OA), } \\
\text { 1980-1989 }\end{array}$ & $\begin{array}{c}\text { Log of } \\
\text { average } \\
\text { annual } \\
\text { net oDA, } \\
1990- \\
1999\end{array}$ & $\begin{array}{c}\text { Log of } \\
\text { average } \\
\text { annual } \\
\text { net IDA, } \\
\text { 1990-1999 }\end{array}$ & $\begin{array}{c}\text { Log of } \\
\text { average } \\
\text { annual } \\
\text { net ODA, } \\
1990-1999\end{array}$ \\
\hline $\begin{array}{l}\text { Log population } \\
1980 \text { [1990] }\end{array}$ & $\begin{array}{l}0.914 \\
(1.73) \star\end{array}$ & $\begin{array}{l}-0.206 \\
(0.28)\end{array}$ & $\begin{array}{c}1.766 \\
(3.96) * * *\end{array}$ & $\begin{array}{c}1.156 \\
(3.04) * * \\
\star\end{array}$ & $\begin{array}{l}1.600 \\
(1.88) *\end{array}$ & $\begin{array}{c}2.664 \\
(4.92) * \star \star\end{array}$ \\
\hline $\begin{array}{l}\text { Log population } \\
1980 \text { [1990] } \\
\text { squared }\end{array}$ & $\begin{array}{l}-0.018 \\
(1.12)\end{array}$ & $\begin{array}{l}0.019 \\
(0.86)\end{array}$ & $\begin{array}{c}-0.039 \\
(2.82) * \star \star\end{array}$ & $\begin{array}{l}-0.023 \\
(2.00) * \star\end{array}$ & $\begin{array}{l}-0.033 \\
(1.38)\end{array}$ & $\begin{array}{l}-0.066 \\
(4.05) * * *\end{array}$ \\
\hline $\begin{array}{l}\text { Log per capita } \\
\text { GDP } 1980 \text { [1990] }\end{array}$ & $\begin{array}{l}3.446 \\
(1.11)\end{array}$ & $\begin{array}{c}23.462 \\
(4.55) * \star *\end{array}$ & $\begin{array}{r}-0.225 \\
(0.05)\end{array}$ & $\begin{array}{l}4.357 \\
(1.97) *\end{array}$ & $\begin{array}{l}13.355 \\
(2.66) * \star\end{array}$ & $\begin{array}{r}-2.439 \\
(0.79)\end{array}$ \\
\hline $\begin{array}{l}\text { Log per capita } \\
\text { GDP } 1980 \text { [1990] } \\
\text { squared }\end{array}$ & $\begin{array}{c}-0.254 \\
(1.24)\end{array}$ & $\begin{array}{c}-1.749 \\
(4.76) \star \star \star\end{array}$ & $\begin{array}{l}0.025 \\
(0.08)\end{array}$ & $\begin{array}{l}-0.316 \\
(2.16) \star \star\end{array}$ & $\begin{array}{l}-0.946 \\
(2.64) * \star\end{array}$ & $\begin{array}{l}0.188 \\
(0.86)\end{array}$ \\
\hline $\begin{array}{l}\text { Freedom House } \\
\text { 1980-1989 } \\
{[1990-1999]}\end{array}$ & $\begin{array}{r}-0.050 \\
(0.25)\end{array}$ & $\begin{array}{l}-0.386 \\
(1.16)\end{array}$ & $\begin{array}{c}-0.024 \\
(0.15)\end{array}$ & $\begin{array}{l}-0.233 \\
(1.55)\end{array}$ & $\begin{array}{l}-0.528 \\
(2.71) \star \star\end{array}$ & $\begin{array}{c}-0.315 \\
(2.91) * * *\end{array}$ \\
\hline $\begin{array}{l}\text { Law } 1980-1989 \\
{[1990-1999]}\end{array}$ & $\begin{array}{r}-0.090 \\
(0.86)\end{array}$ & $\begin{array}{l}-0.139 \\
(0.98)\end{array}$ & $\begin{array}{l}0.020 \\
(0.23)\end{array}$ & $\begin{array}{l}0.078 \\
(0.82)\end{array}$ & $\begin{array}{c}0.274 \\
(1.97)^{*}\end{array}$ & $\begin{array}{l}0.133 \\
(1.36)\end{array}$ \\
\hline Constant & $\begin{array}{r}-1.618 \\
(0.14) \\
\end{array}$ & $\begin{array}{c}-60.897 \\
(3.53) * \star \star \\
\end{array}$ & $\begin{array}{l}1.843 \\
(0.13) \\
\end{array}$ & $\begin{array}{r}-7.502 \\
(0.84) \\
\end{array}$ & $\begin{array}{l}-45.744 \\
(3.73) \star \star \star \\
\end{array}$ & $\begin{array}{l}2.268 \\
(0.24) \\
\end{array}$ \\
\hline Observations & 70 & 42 & 42 & 83 & 40 & 40 \\
\hline R-squared & 0.46 & 0.76 & 0.78 & 0.59 & 0.75 & 0.81 \\
\hline$F$ test & 0.40 & 1.08 & 0.04 & 1.80 & 6.33 & 4.53 \\
\hline Prob $>F$ & 0.67 & 0.35 & 0.97 & 0.17 & 0.00 & 0.02 \\
\hline
\end{tabular}

Notes:

Dependent variables are net aid flows in $1980 \mathrm{~s}$ and $1990 \mathrm{~s}$

Robust $t$ statistics in parentheses

* significant at $10 \% ; * \star$ significant at $5 \% ; * \star *$ significant at $1 \%$

$F$ test is test of joint significance of Freedom House Index and ICRG index 
Table 2. Aid and Growth in the 1990s

\begin{tabular}{|c|c|c|c|c|c|c|}
\hline & $(1)$ & $\begin{array}{l}\text { OLS } \\
(2)\end{array}$ & $(3)$ & $(4)$ & $\begin{array}{l}I V \\
(5)\end{array}$ & $(6)$ \\
\hline & Growth9099 & Growth9099 & Growth9099 & Growth9099 & Growth9099 & Growth9099 \\
\hline $\begin{array}{l}\text { Log per capita } \\
\text { GDP } 1990\end{array}$ & $\begin{array}{l}-0.012 \\
(2.37) \star \star\end{array}$ & $\begin{array}{r}-0.007 \\
(1.04)\end{array}$ & $\begin{array}{c}-0.004 \\
(0.91)\end{array}$ & $\begin{array}{l}0.016 \\
(1.05)\end{array}$ & $\begin{array}{l}0.009 \\
(0.86)\end{array}$ & $\begin{array}{l}0.021 \\
(1.56)\end{array}$ \\
\hline Institutions & $\begin{array}{c}0.022 \\
(3.67) * * \star\end{array}$ & $\begin{array}{c}0.020 \\
(3.49) * \star \star\end{array}$ & $\begin{array}{c}0.015 \\
(3.08) * \star *\end{array}$ & $\begin{array}{l}-0.019 \\
(0.84)\end{array}$ & $\begin{array}{l}0.006 \\
(0.54)\end{array}$ & $\begin{array}{r}-0.012 \\
(0.71)\end{array}$ \\
\hline Aid/GDP & $\begin{array}{l}-0.244 \\
(1.83) *\end{array}$ & $\begin{array}{l}0.002 \\
(0.01)\end{array}$ & $\begin{array}{l}-0.114 \\
(0.82)\end{array}$ & $\begin{array}{r}-0.238 \\
(0.95)\end{array}$ & $\begin{array}{c}0.237 \\
(0.65)\end{array}$ & $\begin{array}{l}0.036 \\
(0.15)\end{array}$ \\
\hline AFR & & $\begin{array}{r}-0.004 \\
(0.27)\end{array}$ & & & $\begin{array}{l}0.001 \\
(0.03)\end{array}$ & \\
\hline EAP & & $\begin{array}{c}0.029 \\
(2.45) * *\end{array}$ & $\begin{array}{c}0.021 \\
(2.63) * \star *\end{array}$ & & $\begin{array}{c}0.035 \\
(2.34) * *\end{array}$ & $\begin{array}{c}0.024 \\
(2.29) * \star\end{array}$ \\
\hline FSU & & $\begin{array}{l}-0.039 \\
(2.02) * \star\end{array}$ & $\begin{array}{c}-0.051 \\
(2.86) * \star \star\end{array}$ & & $\begin{array}{c}-0.053 \\
(2.65) * \star \star\end{array}$ & $\begin{array}{c}-0.082 \\
(3.20) * \star \star\end{array}$ \\
\hline LAC & & $\begin{array}{c}0.019 \\
(2.32) * *\end{array}$ & & & $\begin{array}{l}0.020 \\
(1.43)\end{array}$ & \\
\hline MENA & & $\begin{array}{c}0.021 \\
(1.75) \star\end{array}$ & & & $\begin{array}{l}0.022 \\
(1.34)\end{array}$ & \\
\hline SAR & & $\begin{array}{l}0.024 \\
(1.60)\end{array}$ & $\begin{array}{c}0.017 \\
(2.11) * *\end{array}$ & & $\begin{array}{l}0.038 \\
(1.74)^{*}\end{array}$ & $\begin{array}{l}0.030 \\
(1.98) * *\end{array}$ \\
\hline Constant & $\begin{array}{c}0.119 \\
(2.62) * *\end{array}$ & $\begin{array}{l}0.059 \\
(0.98) \\
\end{array}$ & $\begin{array}{l}0.049 \\
(1.13) \\
\end{array}$ & $\begin{array}{l}-0.116 \\
(0.91) \\
\end{array}$ & $\begin{array}{r}-0.079 \\
(0.83) \\
\end{array}$ & $\begin{array}{r}-0.159 \\
(1.46) \\
\end{array}$ \\
\hline Observations & 124 & 124 & 124 & 124 & 124 & 124 \\
\hline R-squared & 0.15 & 0.36 & 0.26 & & & \\
\hline $\begin{array}{l}\text { OID: Sargan } \\
\text { statistic }\end{array}$ & & & & 5.12 & 6.32 & 3.63 \\
\hline $\begin{array}{l}\text { OID: Chi-sq p- } \\
\text { value }\end{array}$ & & & & 0.40 & 0.28 & 0.60 \\
\hline
\end{tabular}

Notes:

Dependent variable is the growth rate of per capita GDP in 1990s

Robust $t$ statistics in parentheses

* significant at $10 \%$; * significant at $5 \% ; * \star *$ significant at $1 \%$ 


\section{Table 3. First-stage Regressions}

\begin{tabular}{|c|c|c|c|c|}
\hline & (1) & $(2)$ & (3) & $(4)$ \\
\hline & $\begin{array}{c}\text { Log per capita } \\
\text { GDP } 1990\end{array}$ & Institutions & Aid/GDP & Aid*Institutions \\
\hline $\begin{array}{l}\text { Log population } \\
1990\end{array}$ & $\begin{array}{l}-0.605 \\
(1.27)\end{array}$ & $\begin{array}{l}0.045 \\
(0.20)\end{array}$ & $\begin{array}{l}0.003 \\
(0.17)\end{array}$ & $\begin{array}{r}-0.002 \\
(0.21)\end{array}$ \\
\hline $\begin{array}{l}\text { Log population } \\
1990 \text { squared }\end{array}$ & $\begin{array}{l}0.015 \\
(1.03)\end{array}$ & $\begin{array}{r}-0.001 \\
(0.19)\end{array}$ & $\begin{array}{r}-0.000 \\
(0.86)\end{array}$ & $\begin{array}{l}0.000 \\
(0.94)\end{array}$ \\
\hline $\begin{array}{l}\text { Distance from } \\
\text { equator }\end{array}$ & $\begin{array}{l}0.038 \\
(1.05)\end{array}$ & $\begin{array}{c}0.069 \\
(2.64) \star \star \star\end{array}$ & $\begin{array}{c}-0.003 \\
(3.14) \star \star \star\end{array}$ & $\begin{array}{c}0.002 \\
(2.21) \star \star\end{array}$ \\
\hline $\begin{array}{l}\text { Fraction } \\
\text { speaking } \\
\text { English }\end{array}$ & $\begin{array}{l}0.566 \\
(0.37)\end{array}$ & $\begin{array}{c}-1.483 \\
(1.42)\end{array}$ & $\begin{array}{r}-0.087 \\
(0.83)\end{array}$ & $\begin{array}{r}-0.008 \\
(0.27)\end{array}$ \\
\hline $\begin{array}{l}\text { Fraction } \\
\text { speaking } \\
\text { European } \\
\text { language }\end{array}$ & $\begin{array}{r}-1.770 \\
(1.21)\end{array}$ & $\begin{array}{l}0.418 \\
(0.39)\end{array}$ & $\begin{array}{r}-0.010 \\
(0.11)\end{array}$ & $\begin{array}{c}0.096 \\
(2.36) \star \star\end{array}$ \\
\hline pop*dist & $\begin{array}{l}0.000 \\
(0.13)\end{array}$ & $\begin{array}{l}-0.003 \\
(1.49)\end{array}$ & $\begin{array}{c}0.000 \\
(2.63) \star \star \star\end{array}$ & $\begin{array}{l}-0.000 \\
(1.90) *\end{array}$ \\
\hline pop*eng & $\begin{array}{l}-0.023 \\
(0.25)\end{array}$ & $\begin{array}{c}0.125 \\
(1.95) \star\end{array}$ & $\begin{array}{l}0.005 \\
(0.86)\end{array}$ & $\begin{array}{l}0.000 \\
(0.26)\end{array}$ \\
\hline pop*eur & $\begin{array}{l}0.167 \\
(1.90) \star\end{array}$ & $\begin{array}{l}0.010 \\
(0.16)\end{array}$ & $\begin{array}{l}-0.000 \\
(0.07)\end{array}$ & $\begin{array}{c}-0.005 \\
(2.19) \star \star\end{array}$ \\
\hline Constant & $\begin{array}{c}12.765 \\
(3.24) \star \star \star \\
\end{array}$ & $\begin{array}{r}-1.135 \\
(0.66) \\
\end{array}$ & $\begin{array}{l}0.097 \\
(0.66) \\
\end{array}$ & $\begin{array}{c}-0.046 \\
(0.52) \\
\end{array}$ \\
\hline Observations & 124 & 124 & 124 & 124 \\
\hline R-squared & 0.60 & 0.60 & 0.37 & 0.26 \\
\hline F test & 30.31 & 45.11 & $11 \cdot 12$ & 4.74 \\
\hline Prob $>F$ & 0.00 & 0.00 & 0.00 & 0.00 \\
\hline
\end{tabular}

Notes:

Dependent variables are endogenous regressors in Table 2 Robust $t$ statistics in parentheses

* significant at $10 \%$; ** significant at $5 \%$; *** significant at $1 \%$

$F$ test is test of joint significance of all the regressors 
Table 4. Correlations among Explanatory Variables

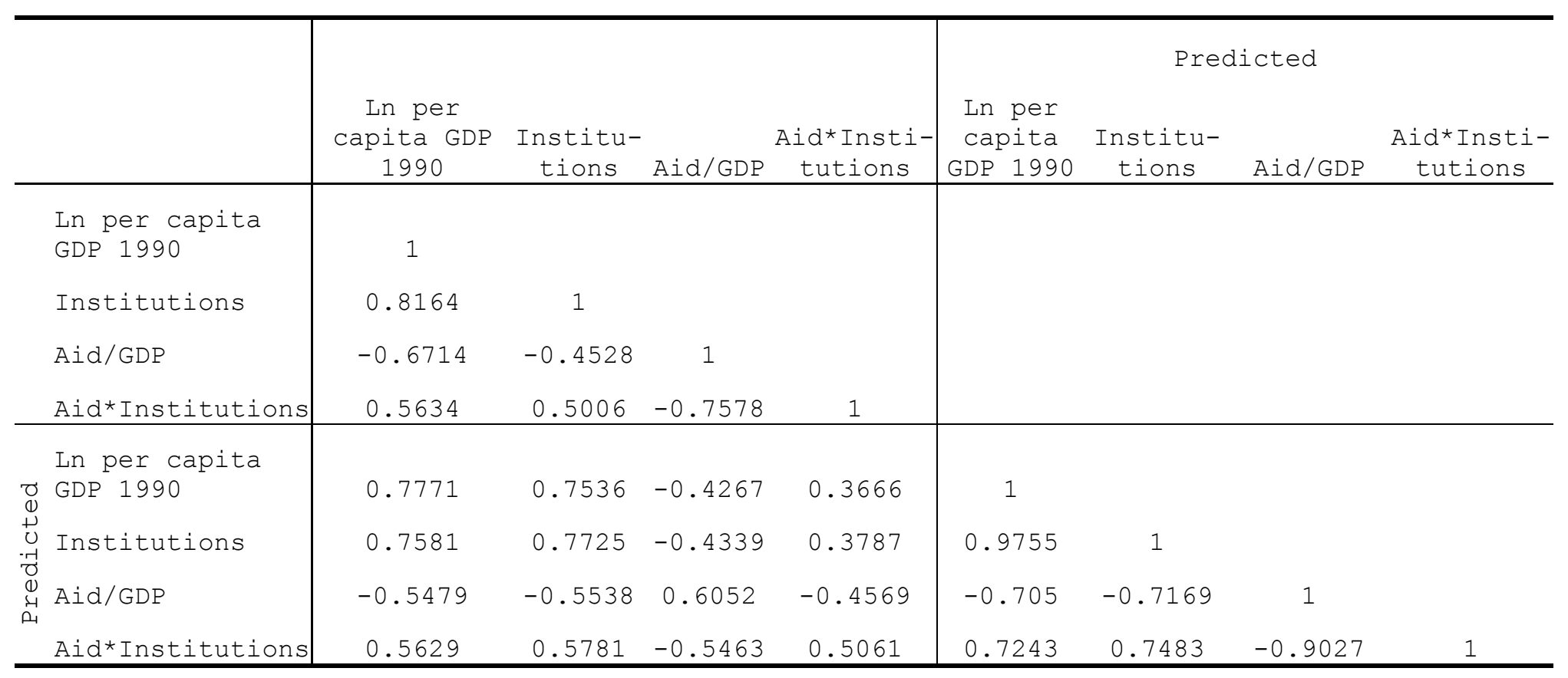


Table 5. Aid, Growth, and Diminishing Returns in the 1990s

\begin{tabular}{|c|c|c|c|c|}
\hline & \multicolumn{2}{|c|}{ OLS } & \multicolumn{2}{|c|}{ IV } \\
\hline & $(1)$ & $(2)$ & $(3)$ & $(4)$ \\
\hline & Growth9099 & Growth9099 & Growth9099 & Growth9099 \\
\hline $\begin{array}{l}\text { Log per capita GDP } \\
1990\end{array}$ & $\begin{array}{l}-0.015 \\
(2.57) \star \star\end{array}$ & $\begin{array}{l}-0.006 \\
(1.09)\end{array}$ & $\begin{array}{l}0.017 \\
(0.92)\end{array}$ & $\begin{array}{l}0.027 \\
(1.42)\end{array}$ \\
\hline Institutions & $\begin{array}{c}0.022 \\
(3.67) * \star \star\end{array}$ & $\begin{array}{l}0.015 \\
(3.11) \star \star \star\end{array}$ & $\begin{array}{c}-0.019 \\
(0.82)\end{array}$ & $\begin{array}{l}-0.016 \\
(0.74)\end{array}$ \\
\hline Aid/GDP & $\begin{array}{l}-0.562 \\
(2.02) \star \star\end{array}$ & $\begin{array}{l}-0.325 \\
(1.03)\end{array}$ & $\begin{array}{l}-0.123 \\
(0.09)\end{array}$ & $\begin{array}{l}0.894 \\
(0.60)\end{array}$ \\
\hline Aid/GDP squared & $\begin{array}{l}2.638 \\
(1.76) *\end{array}$ & $\begin{array}{l}1.653 \\
(1.05)\end{array}$ & $\begin{array}{l}-1.411 \\
(0.08)\end{array}$ & $\begin{array}{l}-10.095 \\
(0.59)\end{array}$ \\
\hline EAP & & $\begin{array}{c}0.020 \\
(2.43) \star \star\end{array}$ & & $\begin{array}{l}0.026 \\
(2.01) \star \star\end{array}$ \\
\hline SAR & & $\begin{array}{l}0.014 \\
(1.57)\end{array}$ & & $\begin{array}{c}0.033 \\
(1.77) *\end{array}$ \\
\hline FSU & & $\begin{array}{l}-0.051 \\
(2.85) \star \star \star\end{array}$ & & $\begin{array}{l}-0.086 \\
(2.77) * \star \star\end{array}$ \\
\hline Constant & $\begin{array}{c}0.142 \\
(2.80) * \star \star\end{array}$ & $\begin{array}{l}0.067 \\
(1.27)\end{array}$ & $\begin{array}{c}-0.124 \\
(0.79) \\
\end{array}$ & $\begin{array}{r}-0.217 \\
(1.34) \\
\end{array}$ \\
\hline Observations & 124 & 124 & 124 & 124 \\
\hline R-squared & 0.17 & 0.27 & & \\
\hline OID: Sargan statistic & & & 4.96 & 2.26 \\
\hline OID: Chi-sq p-value & & & 0.29 & 0.69 \\
\hline
\end{tabular}

Notes:

Dependent variable is growth rate of per capita GDP in 1990s Robust $t$ statistics in parentheses

* significant at $10 \%$; ** significant at $5 \%$; *** significant at $1 \%$ 
Table 6. Aid, Growth, and Institutions in the 1990s

\begin{tabular}{|c|c|c|c|c|}
\hline & \multicolumn{2}{|c|}{ OLS } & \multicolumn{2}{|c|}{ IV } \\
\hline & (1) & $(2)$ & (3) & (4) \\
\hline & Growth9099 & Growth9099 & Growth9099 & Growth9099 \\
\hline $\begin{array}{l}\text { Log per capita GDP } \\
1990\end{array}$ & $\begin{array}{l}-0.012 \\
(2.18) \star \star\end{array}$ & $\begin{array}{l}-0.004 \\
(0.71)\end{array}$ & $\begin{array}{l}0.019 \\
(1.13)\end{array}$ & $\begin{array}{l}0.021 \\
(1.52)\end{array}$ \\
\hline Institutions & $\begin{array}{c}0.021 \\
(3.55) \star \star \star\end{array}$ & $\begin{array}{c}0.013 \\
(2.92) * \star \star\end{array}$ & $\begin{array}{r}-0.028 \\
(1.10)\end{array}$ & $\begin{array}{l}-0.017 \\
(0.91)\end{array}$ \\
\hline Aid/GDP & $\begin{array}{r}-0.189 \\
(0.93)\end{array}$ & $\begin{array}{r}-0.031 \\
(0.15)\end{array}$ & $\begin{array}{l}0.361 \\
(0.80)\end{array}$ & $\begin{array}{l}0.501 \\
(1.30)\end{array}$ \\
\hline Aid*Institutions & $\begin{array}{l}0.112 \\
(0.39)\end{array}$ & $\begin{array}{l}0.171 \\
(0.64)\end{array}$ & $\begin{array}{l}1.467 \\
(1.66) *\end{array}$ & $\begin{array}{l}1.171 \\
(1.64)\end{array}$ \\
\hline EAP & & $\begin{array}{c}0.021 \\
(2.60) * *\end{array}$ & & $\begin{array}{c}0.023 \\
(2.02) * \star\end{array}$ \\
\hline SAR & & $\begin{array}{c}0.017 \\
(2.09) * *\end{array}$ & & $\begin{array}{l}0.027 \\
(1.70) *\end{array}$ \\
\hline FSU & & $\begin{array}{l}-0.052 \\
(2.93) * \star \star\end{array}$ & & $\begin{array}{l}-0.086 \\
(3.14) * \star \star\end{array}$ \\
\hline Constant & $\begin{array}{c}0.115 \\
(2.40) * * \\
\end{array}$ & $\begin{array}{l}0.043 \\
(0.92) \\
\end{array}$ & $\begin{array}{l}-0.142 \\
(1.01) \\
\end{array}$ & $\begin{array}{l}-0.163 \\
(1.42) \\
\end{array}$ \\
\hline Observations & 124 & 124 & 124 & 124 \\
\hline R-squared & 0.16 & 0.27 & & \\
\hline OID: Sargan statistic & & & 1.45 & 0.55 \\
\hline OID: Chi-sq p-value & & & 0.84 & 0.97 \\
\hline
\end{tabular}

Notes:

Dependent variable is growth rate of per capita GDP in $1990 \mathrm{~s}$

Robust $t$ statistics in parentheses

* significant at $10 \% ; * *$ significant at $5 \% ; * * *$ significant at $1 \%$ 
Table 7. Aid, Growth, and Institutions in the 1990s without Haiti and Equatorial Guinea

\begin{tabular}{|c|c|c|c|c|}
\hline & \multicolumn{2}{|c|}{$O L S$} & \multicolumn{2}{|c|}{ IV } \\
\hline & $(1)$ & $(2)$ & (3) & $(4)$ \\
\hline & Growth9099 & Growth9099 & Growth9099 & Growth9099 \\
\hline $\begin{array}{l}\text { Log per capita } \\
\text { GDP } 1990\end{array}$ & $\begin{array}{l}-0.011 \\
(2.13) \star \star\end{array}$ & $\begin{array}{r}-0.002 \\
(0.45)\end{array}$ & $\begin{array}{l}0.009 \\
(0.54)\end{array}$ & $\begin{array}{l}0.012 \\
(0.90)\end{array}$ \\
\hline Institutions & $\begin{array}{c}0.021 \\
(3.65) * * \star\end{array}$ & $\begin{array}{c}0.013 \\
(3.06) * \star *\end{array}$ & $\begin{array}{r}-0.017 \\
(0.71)\end{array}$ & $\begin{array}{l}-0.009 \\
(0.54)\end{array}$ \\
\hline $\mathrm{Aid} / \mathrm{GDP}$ & $\begin{array}{r}-0.057 \\
(0.34)\end{array}$ & $\begin{array}{l}0.120 \\
(0.71)\end{array}$ & $\begin{array}{l}0.253 \\
(0.67)\end{array}$ & $\begin{array}{l}0.338 \\
(1.09)\end{array}$ \\
\hline Aid*Institutions & $\begin{array}{l}0.431 \\
(1.57)\end{array}$ & $\begin{array}{c}0.484 \\
(2.01) \star \star\end{array}$ & $\begin{array}{c}1.883 \\
(2.13) * *\end{array}$ & $\begin{array}{c}1.497 \\
(2.10) * \star\end{array}$ \\
\hline $\mathrm{EAP}$ & & $\begin{array}{c}0.024 \\
(2.95) * \star \star\end{array}$ & & $\begin{array}{l}0.020 \\
(1.95) *\end{array}$ \\
\hline SAR & & $\begin{array}{l}0.020 \\
(3.00) * \star \star\end{array}$ & & $\begin{array}{l}0.021 \\
(1.38)\end{array}$ \\
\hline FSU & & $\begin{array}{c}-0.051 \\
(2.88) * * \star\end{array}$ & & $\begin{array}{l}-0.078 \\
(3.13) * \star \star\end{array}$ \\
\hline Constant & $\begin{array}{c}0.104 \\
(2.35) * *\end{array}$ & $\begin{array}{l}0.026 \\
(0.67)\end{array}$ & $\begin{array}{l}-0.054 \\
(0.39)\end{array}$ & $\begin{array}{r}-0.086 \\
(0.76)\end{array}$ \\
\hline Observations & 122 & 122 & 122 & 122 \\
\hline R-squared & 0.25 & 0.39 & & \\
\hline $\begin{array}{l}\text { OID: Sargan } \\
\text { statistic }\end{array}$ & & & 1.26 & 0.71 \\
\hline $\begin{array}{l}\text { OID: Chi-sq p- } \\
\text { value }\end{array}$ & & & 0.87 & 0.95 \\
\hline
\end{tabular}

Notes:

Dependent variable is growth rate of per capita GDP in $19990 \mathrm{~s}$

Robust $t$ statistics in parentheses

* significant at $10 \% ; * *$ significant at $5 \% ; * * *$ significant at $1 \%$ 
Table 8. Testing for Instrument Quality with Shea Partial R-Squared

\begin{tabular}{|c|c|c|c|c|c|}
\hline & & \multicolumn{4}{|c|}{ Bars } \\
\hline & & $(1)$ & $(2)$ & (3) & $(4)$ \\
\hline \multirow{7}{*}{$\begin{array}{l}02 \\
0 \\
0 \\
-1 \\
-1 \\
E \\
E\end{array}$} & & Aid/GDP & Institutions & Aid*Institutions & $\begin{array}{c}\text { Log per } \\
\text { capita GDE }\end{array}$ \\
\hline & Aid/GDP & $\begin{array}{c}1.000 \\
(3.06) \star \star \star\end{array}$ & & & \\
\hline & Institutions & & $\begin{array}{c}1.000 \\
(2.88) \star \star \star\end{array}$ & & \\
\hline & Aid*Institutions & & & $\begin{array}{c}1.000 \\
(2.67) \star \star \star\end{array}$ & \\
\hline & Log per capita GDP & & & & $\begin{array}{c}1.000 \\
(3.62) * * *\end{array}$ \\
\hline & Observations & 124 & 124 & 124 & 124 \\
\hline & $\mathrm{R}$-squared & 0.22 & 0.09 & 0.11 & 0.14 \\
\hline
\end{tabular}

Notes:

Robust $t$ statistics in parentheses

* significant at $10 \%$; ** significant at $5 \% ; * * *$ significant at $1 \%$ 
Table 9. Aid, Growth, and Institutions in the 1990s - No Initial Per Capita GDP

\begin{tabular}{|c|c|c|c|c|}
\hline & \multicolumn{2}{|c|}{ OLS } & \multicolumn{2}{|c|}{ IV } \\
\hline & $(1)$ & $(2)$ & $(3)$ & $(4)$ \\
\hline & Growth 9099 & Growth9099 & Growth9099 & Growth9099 \\
\hline Institutions & $\begin{array}{c}0.010 \\
(2.48) * *\end{array}$ & $\begin{array}{c}0.010 \\
(2.43) \star \star\end{array}$ & $\begin{array}{l}-0.001 \\
(0.11)\end{array}$ & $\begin{array}{l}0.009 \\
(1.39)\end{array}$ \\
\hline $\mathrm{Aid} / \mathrm{GDP}$ & $\begin{array}{l}0.030 \\
(0.21)\end{array}$ & $\begin{array}{l}0.037 \\
(0.25)\end{array}$ & $\begin{array}{l}0.304 \\
(0.79)\end{array}$ & $\begin{array}{l}0.431 \\
(1.22)\end{array}$ \\
\hline Aid*Institutions & $\begin{array}{l}0.200 \\
(0.81)\end{array}$ & $\begin{array}{l}0.197 \\
(0.79)\end{array}$ & $\begin{array}{l}1.357 \\
(1.82) *\end{array}$ & $\begin{array}{l}1.143 \\
(1.75) *\end{array}$ \\
\hline $\mathrm{EAP}$ & & $\begin{array}{c}0.022 \\
(2.74) \star \star \star\end{array}$ & & $\begin{array}{c}0.022 \\
(2.11) * *\end{array}$ \\
\hline SAR & & $\begin{array}{c}0.019 \\
(3.47) * \star *\end{array}$ & & $\begin{array}{l}0.019 \\
(1.36)\end{array}$ \\
\hline FSU & & $\begin{array}{c}-0.056 \\
(3.08) \star \star \star\end{array}$ & & $\begin{array}{c}-0.056 \\
(3.21) * \star \star\end{array}$ \\
\hline Constant & $\begin{array}{c}0.012 \\
(3.29) * * * \\
\end{array}$ & $\begin{array}{c}0.011 \\
(2.84) * * * \\
\end{array}$ & $\begin{array}{c}0.017 \\
(2.96) * \star \star \\
\end{array}$ & $\begin{array}{c}0.011 \\
(1.67) * \\
\end{array}$ \\
\hline Observations & 124 & 124 & 124 & 124 \\
\hline R-squared & 0.11 & 0.26 & & \\
\hline $\begin{array}{l}\text { OID: Sargan } \\
\text { statistic }\end{array}$ & & & 3.78 & 3.37 \\
\hline $\begin{array}{l}\text { OID: Chi-sq p- } \\
\text { value }\end{array}$ & & & 0.58 & 0.64 \\
\hline
\end{tabular}

Notes:

Dependent variable is growth rate of per capita GDP in $1990 \mathrm{~s}$

Robust $t$ statistics in parentheses

* significant at $10 \%$; ** significant at $5 \%$; $* \star *$ significant at $1 \%$ 
Table 10. Aid, Growth, and Institutions in the 1990s - Initial GDP/capita and Institutions Exogenous

\begin{tabular}{|c|c|c|c|c|}
\hline & \multicolumn{2}{|c|}{ OLS } & \multicolumn{2}{|c|}{ IV } \\
\hline & $(1)$ & $(2)$ & $(3)$ & $(4)$ \\
\hline & Growth9099 & Growth9099 & Growth9099 & Growth9099 \\
\hline $\begin{array}{l}\text { Log per capita } \\
\text { GDP } 1990\end{array}$ & $\begin{array}{l}-0.012 \\
(2.18) \star \star\end{array}$ & $\begin{array}{c}-0.004 \\
(0.71)\end{array}$ & $\begin{array}{r}-0.006 \\
(0.95)\end{array}$ & $\begin{array}{l}0.004 \\
(0.64)\end{array}$ \\
\hline Institutions & $\begin{array}{c}0.021 \\
(3.55) * * *\end{array}$ & $\begin{array}{c}0.013 \\
(2.92) * * *\end{array}$ & $\begin{array}{l}0.011 \\
(1.40)\end{array}$ & $\begin{array}{l}0.006 \\
(0.84)\end{array}$ \\
\hline $\mathrm{Aid} / \mathrm{GDP}$ & $\begin{array}{r}-0.189 \\
(0.93)\end{array}$ & $\begin{array}{r}-0.031 \\
(0.15)\end{array}$ & $\begin{array}{l}0.467 \\
(1.30)\end{array}$ & $\begin{array}{l}0.458 \\
(1.48)\end{array}$ \\
\hline Aid*Institutions & $\begin{array}{l}0.112 \\
(0.39)\end{array}$ & $\begin{array}{l}0.171 \\
(0.64)\end{array}$ & $\begin{array}{l}1.326 \\
(1.96) *\end{array}$ & $\begin{array}{l}0.690 \\
(1.24)\end{array}$ \\
\hline EAP & & $\begin{array}{c}0.021 \\
(2.60) * \star\end{array}$ & & $\begin{array}{c}0.026 \\
(2.65) * \star \star\end{array}$ \\
\hline SAR & & $\begin{array}{c}0.017 \\
(2.09) * \star\end{array}$ & & $\begin{array}{c}0.024 \\
(1.77) *\end{array}$ \\
\hline FSU & & $\begin{array}{c}-0.052 \\
(2.93) * \star \star\end{array}$ & & $\begin{array}{c}-0.057 \\
(3.51) * \star \star\end{array}$ \\
\hline Constant & $\begin{array}{c}0.115 \\
(2.40) * \star\end{array}$ & $\begin{array}{l}0.043 \\
(0.92)\end{array}$ & $\begin{array}{l}0.064 \\
(1.13)\end{array}$ & $\begin{array}{l}-0.029 \\
(0.49)\end{array}$ \\
\hline Observations & 124 & 124 & 124 & 124 \\
\hline R-squared & 0.16 & 0.27 & & \\
\hline $\begin{array}{l}\text { OID: Sargan } \\
\text { statistic }\end{array}$ & & & 6.53 & 7.40 \\
\hline $\begin{array}{l}\text { OID: Chi-sq p- } \\
\text { value }\end{array}$ & & & 0.37 & 0.29 \\
\hline
\end{tabular}

Notes:

Dependent variable is growth rate of per capita GDP in $1990 \mathrm{~s}$

Robust $t$ statistics in parentheses

* significant at $10 \%$; ** significant at $5 \%$; ** significant at $1 \%$ 


\section{Appendix. Variable Names and Descriptions}

\begin{tabular}{|c|c|}
\hline $\begin{array}{l}\text { Variable } \\
\text { Name }\end{array}$ & Description \\
\hline $\operatorname{afr}$ & Dummy [=1 if country is in Africa (WB region)] \\
\hline aidgdp & $\begin{array}{l}\text { (Average annual ODA or OA in the 1990s[DAC]) / (average annual real GDP in the } \\
1990 \mathrm{~s}[\text { Penn World Tables 6.1]) }\end{array}$ \\
\hline aidgdpsq & "aidgdp" squared \\
\hline aidKKZ & Interaction of "aidgdp" and "KKZ96" \\
\hline disteq & $\begin{array}{l}\text { Distance from the equator, measured as absolute value of latitude of the } \\
\text { capital }\end{array}$ \\
\hline eap & Dummy [=1 if country is in East Asia \& Pacific (WB region)] \\
\hline eca & Dummy $[=1$ if country is in Europe \& Central Asia (WB region)] \\
\hline engfrac & \% of population in the country speaking English (Hall and Jones, 1999) \\
\hline eurfrac & $\begin{array}{l}\text { of population in the country speaking a major European language (Hall and } \\
\text { Jones, 1999) }\end{array}$ \\
\hline fh 8089 & $\begin{array}{l}\text { Freedom House Democracy Index (1=most democratic; } 3 \text { = most authoritarian), } \\
\text { average for 1980-1989 }\end{array}$ \\
\hline fh9099 & $\begin{array}{l}\text { Freedom House Democracy Index (1=most democratic; } 3 \text { = most authoritarian), } \\
\text { average for 1990-1999 }\end{array}$ \\
\hline fsu & Dummy $[=1$ if country is in the Former Soviet Union] \\
\hline growth 9099 & Average annual growth of real GDP/capita in the $1990 \mathrm{~s}$ \\
\hline KKZ 96 & $\begin{array}{l}\text { Average of } 6 \text { governance indicators (ranges from }-2 \text { to } 2 \text {, increasing with better } \\
\text { institutions), } 1996 \text { (KKZ 2003) }\end{array}$ \\
\hline lac & Dummy $[=1$ if country is in Latin America \& the Caribbean (WB region)] \\
\hline Inida 8089 & Log of average annual net IDA to the country, 1980-1989 (DAC) \\
\hline Inida9099 & Log of average annual net IDA to the country, 1990-1999 (DAC) \\
\hline Inoda 8089 & Log of average annual net ODA to the country, 1980-1989 (DAC) \\
\hline Inoda9099 & Log of average annual net ODA to the country, 1990-1999 (DAC) \\
\hline lnpop80 & Log of population, 1980 (Penn World Tables 6.1) \\
\hline lnpop80sq & "lnpop80" squared \\
\hline Inpop 90 & Log of Population, 1990 (Penn World Tables 6.1) \\
\hline
\end{tabular}




\begin{tabular}{|c|c|}
\hline lnpop90sq & "Inpop90" squared \\
\hline $\ln y 80$ & $\begin{array}{l}\text { Log of real GDP per capita in constant 1996\$ [chain series], } 1980 \text { (Penn World } \\
\text { Tables 6.1) }\end{array}$ \\
\hline $\operatorname{lny} 80 \mathrm{sq}$ & "lny80" squared \\
\hline $\ln y 90$ & $\begin{array}{l}\text { Log of real GDP per capita in constant 1996\$ [chain series], } 1990 \text { (Penn World } \\
\text { Tables 6.1) }\end{array}$ \\
\hline lny90sq & "lny90" squared \\
\hline mena & Dummy $[=1$ if country is in Middle East \& North Africa (WB region)] \\
\hline popdist & Interaction of "lnpop90" and "disteq" \\
\hline popeng & Interaction of "lnpop90" and "engfrac" \\
\hline popeur & Interaction of "Inpop90" and "eurfrac" \\
\hline rule 8089 & $\begin{array}{l}\text { ICRG index for Rule of Law (ranges from } 1 \text { to } 6 \text {, increasing with better rule of } \\
\text { law), average for 1980-1989 }\end{array}$ \\
\hline rule9099 & $\begin{array}{l}\text { ICRG index for Rule of Law (ranges from } 1 \text { to } 6 \text {, increasing with better rule of } \\
\text { law), average for 1990-1999 }\end{array}$ \\
\hline sar & Dummy [=1 if country is in South Asia (WB region)] \\
\hline
\end{tabular}

